\title{
PERFORMANCE ANALYSIS OF CRYSTALLINE SILICON AND CIGS PHOTOVOLTAIC MODULES IN OUTDOOR MEASUREMENT
}

\author{
ANALIZA PRACY POLIKRYSTALICZNYCH I CIENKOWARSTWOWYCH \\ (TYPU CIGS) MODUŁÓW FOTOWOLTAICZNYCH \\ W LABORATORIUM POLOWYM
}

\begin{abstract}
The outdoor measurements (during two months experiment) of photovoltaic silicon and CIGS modules as well as simulation of energy production during the period experiment are presented in this paper. This paper offer comparison of construction and electrical characteristics of multicrystalline silicon based modules and CIGS based modules. The measuring system for PV modules efficiency research is shown. The nominal power of installed modules is $250 \mathrm{~W}$ for $\mathrm{m}$-Si and $280 \mathrm{~W}$ for CIGS modules. The energy production in outdoor conditions at direct current side and alternating current side of each photovoltaic panel was measured. Each PV panel was also equipped with temperature sensor for screening panel temperature. The photovoltaic panels were connected to the electrical network with micro inverters. To determine the influence of irradiance at sunshine on power conversion efficiency of PV panels, the pyranometer was installed in the plane of the modules. Measurement of the instantaneous power and irradiance gave the information about the efficiency of a particular photovoltaic panels. In the paper all data from research installation were analysed to present the influence of solar cell technology on the power conversion efficiency. The results of energy production show that $\mathrm{m}-\mathrm{Si}$ module produced more energy from square meter $\left(30.9 \mathrm{kWh} / \mathrm{m}^{2}\right)$ than CIGS module $\left(28.0 \mathrm{kWh} / \mathrm{m}^{2}\right)$. Thin film module shows the higher production per $\mathrm{kWp}$ than multicrystalline module: $217.3 \mathrm{kWh} / \mathrm{kWp}$ for CIGS and $201.9 \mathrm{kWh} / \mathrm{kWp}$ for $\mathrm{m}$-Si. The energy production simulation (made by PV SOL software and outdoor measurements test are in the good agreement. Temperature power coefficient for the CIGS module is twice lower than for the multicrystalline silicon module: $0.56 \% /{ }^{\circ} \mathrm{C}$ and $0.35 \% /{ }^{\circ} \mathrm{C}$ for $\mathrm{m}$-Si and CIGS modules, respectively. The obtained results revealed strong influence of irradiance and temperature on energy production by PV panels. Performed studies have a large field of potential application and could improve designing process of PV installation.
\end{abstract}

Keywords: PV modules, crystalline silicon modules, thin-film modules, CIGS

\section{Introduction}

The rapid growth of worldwide energy demand and the associated environmental issue causes the people increasingly focuses on reaping energy from the sun [1]. Therefore the

\footnotetext{
${ }^{1}$ AGH University of Science and Technology, Faculty of Geology, Geophysics and Environmental Protection, Department of Fossil Fuels, al. A. Mickiewicza 30, 30-059 Kraków, Poland, phone +48 126174057

${ }^{2}$ AGH University of Science and Technology, Faculty of Computer Science, Electronics and Telecommunications, Department of Electronics, al. A. Mickiewicza 30, 30-059 Kraków, Poland, phone +48126173614

*Corresponding author: lubon@agh.edu.pl
} 
studies for find out the new materials and develop new technologies are still carried out [2]. As a result two generation of photovoltaic cells were developed [3-6]. The first generation consists of mono and polycrystalline silicon solar cell. Monocrystalline solar cells have the highest efficiency and are the most widespread but simultaneously they are the most expensive. The monocrystalline silicon wafers are cut from a single crystal of silicon. Polycrystalline cells are made from silicon material which are melted and poured into a mold. They are cheaper than monocrystalline PV modules but their efficiency is also lower $[3,4,6,7]$. The second generation of PV includes the solar cell obtained by thin film technologies, such as evaporation, magnetron sputtering and chemical vapour deposition (CVD) [8]. Advantage of this generation is the lower usage of semiconductor material. Moreover the production process of PV cell by thin film technologies is less complicated and consumes less energy and therefore their cost is lower. Thin-film modules are commercially used in several technologies, such as cadmium telluride (CdTe), copper indium gallium diselenide (CIGS), and amorphous silicon (a-Si). In the last few years, a large thin film technology development is observed [9]. According to Photovoltaics report from Fraunhofer Institute [10], in 2016 the share of thin-film modules in the PV market reached about $5 \mathrm{GW}$ while in 2012 it was about $3 \mathrm{GW}$.

However the power conversion efficiency and other photovoltaic parameters are not constant. They are strongly affected by temperature [11] and illumination. Temperature increase reduces the band gap of a semiconductor thereby changing its electrical parameters [12]. Depending on the type of module power loss with temperature increasing may be higher or lower. Therefore it became necessary to know how cell performance changes with varying of these parameters [13].

Changes of the law in Poland contributed to increase interest in photovoltaics. New support system resulting from the law on renewable energy sources will contribute to increasing energy market share by micro energy systems based on PV modules. So far there were not many PV installations in Poland, it means the cell performance in local climate were not determined. Therefore it became necessary to carried out the long term outdoor measurement, in which the performance of solar cell in local weather condition [14] will be studied. Only based on such studies it is possible to select optimal technologies for specific environments, where for example, the sky is often overcast or where the temperature can change dramatically throughout the day [15].

In the AGH-UST Laboratory of Renewable Energy Sources and Energy Saving in Miekinia the photovoltaic installation consists of different types of silicon and thin film modules was built. In the laboratory environments the studies of the solar cell performance in depending on shading, module temperature and solar radiation are carried out. Long-term outdoor measurements allow to direct compare the energy efficiency of different PV modules types in local weather conditions of southern Poland.

\section{Description of the analysed photovoltaic system}

Research installation is built from panels with nominal power $250 \mathrm{~W}$ for $\mathrm{m}-\mathrm{Si}$ and $280 \mathrm{~W}$ for CIGS modules. PV panels are installed at an angle of 33 degrees on the stationary solar panel system on the ground. Because of specific parameters like voltage and current the two CIGS modules are connected in parallel circuit. In measuring station on the DC side (before the micro inverter) multifunction meters: Nemo D4DC are used for each PV panel to get the data such as amount of energy production, actual power, voltage 
and current of PV panel. To convert energy from direct current to alternating current micro inverters are used. Each PV panel supports one micro inverter:

- $\quad$ Micro Reneplus-250 for m-Si module

- $\quad$ StecaGrid 300 for CIGS panel

Parameters such as MPPT DC voltage range, maximum input short circuit current are in the good agreement for PV panels and inverters. On the alternating current side an electrical network analysers: F\&F LE 01MP are used for each PV panel to get the data such as an amount of energy production and actual power of PV panel.

Furthermore the installation includes pyranometer: LP Pyra 03 for the measurement of incoming global solar radiation, located in the plane of the module and resistance temperature sensors: PT-1000 Heraeus, stick to the back side of modules. In this moment all measurements of PV modules are made on the station with fully automatic data logging and storage. This installation consists of eleven different PV panels created in silicon and thin film technology. This paper presents the results for multicrystalline silicon module and CIGS panel. Analysed data are from a time period of two month starting 01.08.2014 to 30.09.2014. During this time the following tests were carried out:

- influence of solar radiation on power conversion efficiency of PV panels,

- $\quad$ energy production recalculated on energy from $\mathrm{kWp}$ and energy generated from square meter of module,

- temperature power coefficient,

- efficiency of inverters,

- comparison the results of the outdoor tests with the simulation results.

Diagram of the installation with all sensors and measuring equipment is shown in the Figure 1.

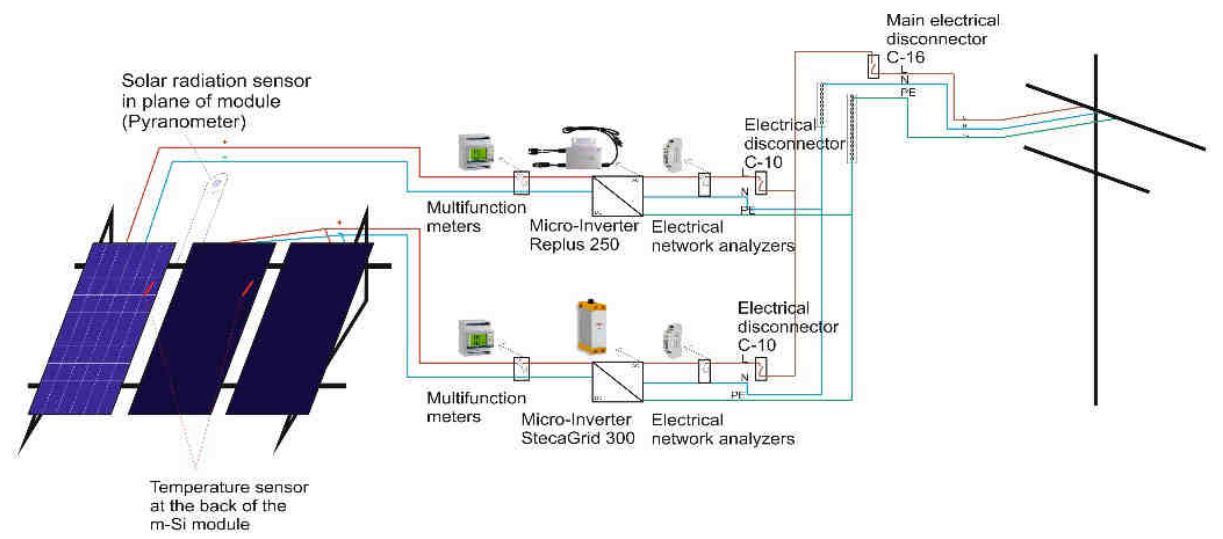

Fig. 1. Diagram of experimental installation

\section{System of collecting and storage data}

Multifunction meters and electrical network analysers are provided with RS485 Modbus RTU protocol. These devices are directly connected to the computer, where data are logged and storage. Data from temperature sensors and form pyranometer are connected to the computer by recorder with TCP/IP protocol. All data are saved every minute. 
Inverters used in installations have their own measuring systems, but they are not accurate enough. Moreover the inverters have two different measuring systems which may give different results. Independent and external measuring system used in installation is giving reliable results for testing PV panels.

\section{Tests}

Comparison of performance of polycrystalline and CIGS modules was carried out based on amount of energy produced by each panel (Table 1). The data from time period of two months (01.08.2014 to 30.09.2014) were selected for analysis. Because of tested photovoltaic panels have different nominal power it was impossible to compare them directly. To compare the energy yields between the multicrystalline Si and thin film modules it was necessary to recalculate the energy production from each PV panels per square meter of installed area and per $\mathrm{kWp}$ (kilowatt-peak) of installed capacity [16]. During the analysis only the energy yield data on the DC side were taken into account. It allowed to exclude the impact of inverters efficiency on the obtained results. This does not preclude the influence of an individual inverter MPPT algorithm on energy production, but current-voltage parameters of photovoltaic module exclude the use of the same inverters.

Based on the results of energy production, shown in Table 1, it is observed that the increase of solar radiation causes increase of energy produced by photovoltaic modules. Noticeable is that energy production recalculated per $\mathrm{kWp}$ is higher from CIGS panel than from $\mathrm{m}$-Si panel. This was repeated for a variety of solar radiation - low, medium and high. The opposite results of energy production are in the recalculation per square meter. In this case more energy is produced form multicrystalline silicon PV than thin film panel. The same situation is observed for each value of solar radiation. Higher production of energy recalculated on square meter from $\mathrm{m}$-Si module is caused by higher efficiency of silicon cell than efficiency of CIGS cell.

Table 1

Comparison of the particular PV modules effectiveness

\begin{tabular}{|l|c|c|}
\hline Date & \multicolumn{2}{|c|}{$01.08 .2014-30.09 .2014$} \\
\hline Type of PV module & $\mathrm{m}-\mathrm{Si}$ & CIGS \\
\hline Nominal power of PV module $[\mathrm{kW}]$ & 0.25 & 0.28 \\
\hline Area of PV module $\left[\mathrm{m}^{2}\right]$ & 1.63 & 2.17 \\
\hline Energy produced within the analysed time period $[\mathrm{kWh}]$ & 50.3 & 60.8 \\
\hline Energy recalculated per $\mathrm{kWp}$ on the DC side $[\mathrm{kWh} / \mathrm{kWp}]$ & 201.9 & 217.3 \\
\hline $\begin{array}{l}\text { Energy recalculated per square meter on the DC side } \\
{\left[\mathrm{kWh} / \mathrm{m}^{2}\right]}\end{array}$ & 30.9 & 28.0 \\
\hline
\end{tabular}

Energy production in regard to the unit surface area or to nominal power is very important in the design of PV installation. In case of situation the area of roof is small then the energy production per square meter should be taken into consideration. If the area of roof is not a problem than energy production from $\mathrm{kWp}$ should be considered. Results of energy production test from multicrystalline silicon and thin film panel realised in a small period of time, presented in Table 4, are coincided with data from longer period of time, shown in Table 1.

The results of outdoor measurements were compared with the effects of simulation carried out using PV SOL Expert 6.0 software for the localization of Miekinia nearby the Krakow. Installation parameters adopted to simulation were the same as the parameters in 
outdoor laboratory and the simulated installation was consist of the same components as a real PV installation. In the first case PV installation was built from one multicrystalline silicon solar module (SunLink PV Co., Ltd. SL 220-20P250) with the nominal power of $250 \mathrm{~W}$ while second installation contained two PV modules CIGS type (TSMC Solar Europe $\mathrm{GmbH}-140 \mathrm{C} 1$ ), each of them with nominal power of $140 \mathrm{~W}$. It was assumed PV modules are directed to the south at the angle of 33 degrees to the ground level. The results of simulation, shown in Table 2, are in good agreement with the data obtained from outdoor laboratory. Its confirmed that installation based on polycrystalline silicon solar cell produces higher amount of energy regarding to the unit area of the PV module, however in relation to nominal power of modules, the installation based on CIGS panels achieves better results.

Table 2

Comparison of energy yields from field test and simulation

\begin{tabular}{|c|c|c|c|c|}
\hline \multirow{2}{*}{ Type of PV module } & \multicolumn{2}{|c|}{$\begin{array}{c}\text { Energy recalculated per square meter } \\
\text { on the DC side }\left[\mathbf{k W h} / \mathbf{m}^{2}\right]\end{array}$} & \multicolumn{2}{|c|}{$\begin{array}{c}\text { Energy recalculated per } \mathbf{k W p} \\
\text { on the DC side [kWh/kWp] }\end{array}$} \\
\cline { 2 - 5 } & Field test & Simulation & Field test & Simulation \\
\hline m-Si & 30.9 & 35.0 & 202 & 228 \\
\hline CIGS & 28.0 & 29.0 & $\mathbf{2 1 7}$ & 252 \\
\hline
\end{tabular}

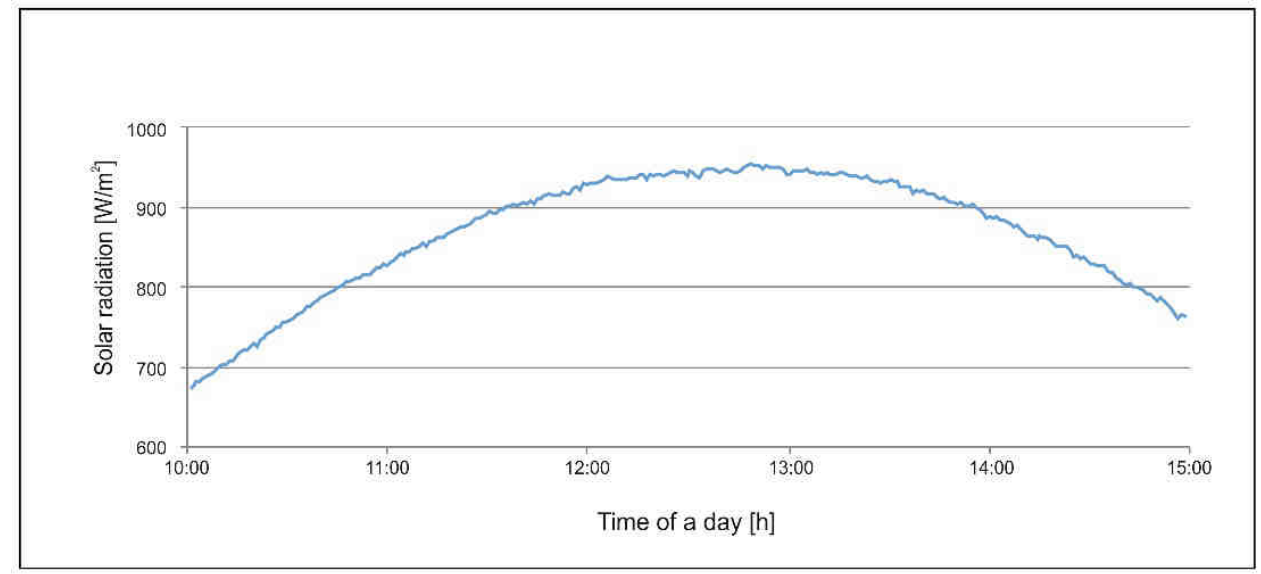

Fig. 2. Solar radiation in the plane of the modules for the test of energy conversion efficiency

By analysis of instantaneous power of PV panel on the DC side and solar radiation in the same moment, the efficiency of energy conversion can be determined. This test allows to show the PV module efficiency for CIGS and m-Si panels. Tests were done for one day since 10 am to $15 \mathrm{pm}$. For this period of time the average of solar radiation was $868.76 \mathrm{~W} / \mathrm{m}^{2}$. The distribution of solar radiation for the analysed interval is shown in Figure 2. During the first part of test the solar radiation was increasing, then the value of solar radiation was similar and in the last part was decreasing.

Temperatures of modules were changing but were close to each other what is shown in the Figure 3. The average efficiency of energy conversion for analysed modules in specified period of time was $13.0 \%$ for $\mathrm{m}-\mathrm{Si} \mathrm{PV}$ panel and $12.6 \%$ for CIGS PV panel. 
The efficiency of PV panel refers directly into yield power from square meter. The data presented in Tables 1 and 4, show that multicrystalline panel produce more energy per square meter than CIGS panel, so they are more efficient.

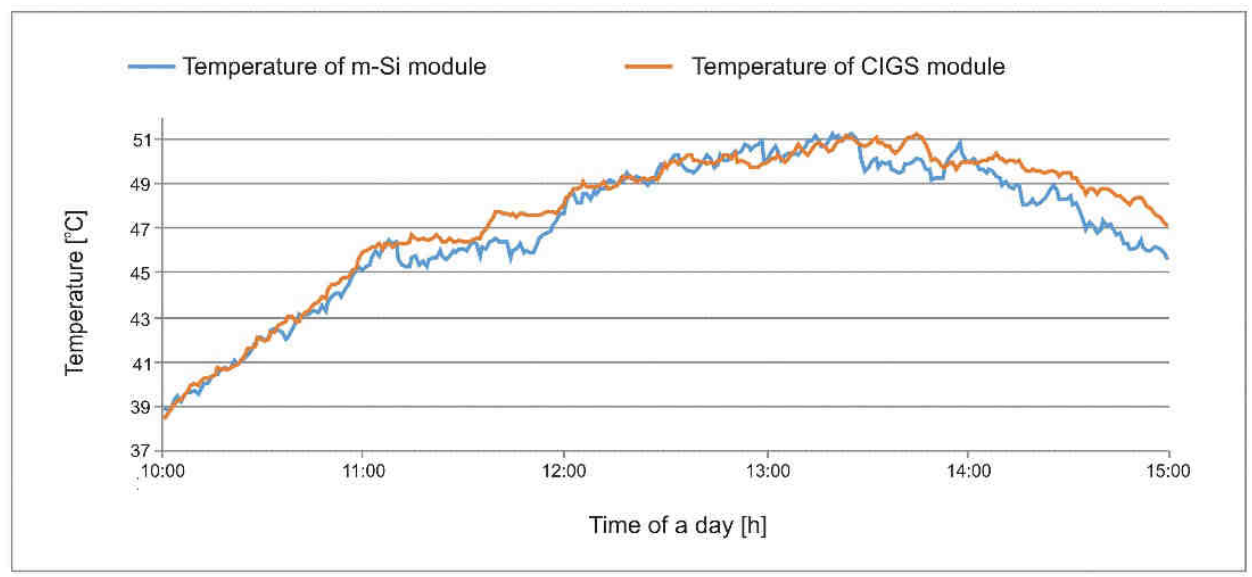

Fig. 3. Temperature of modules in the test of energy conversion efficiency

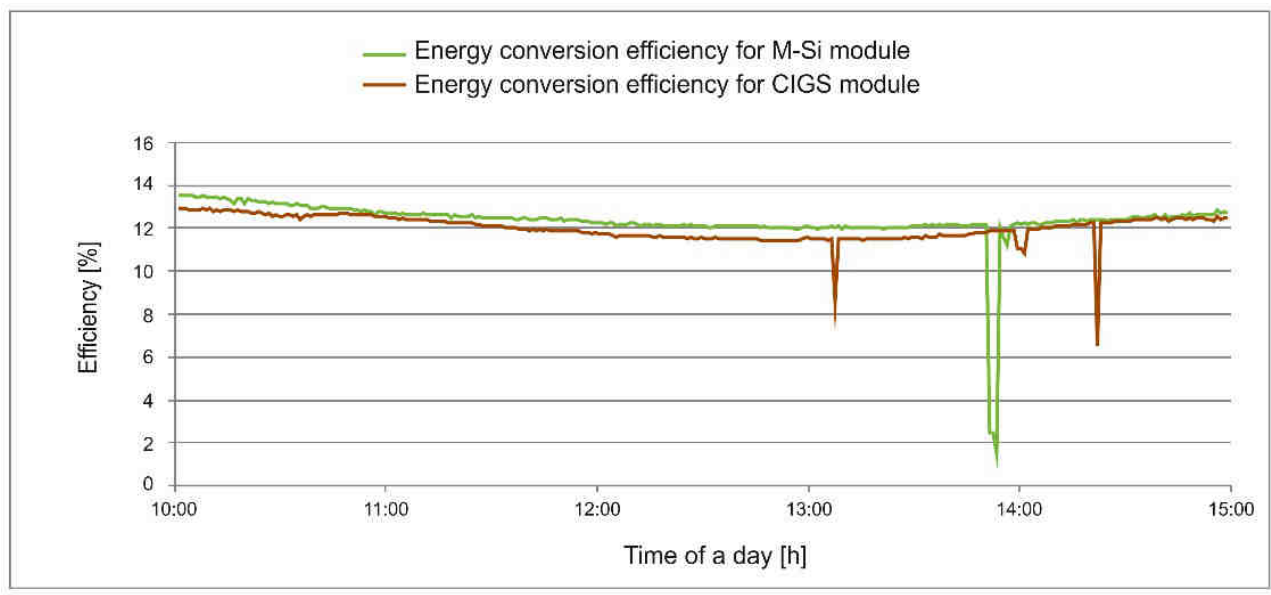

Fig. 4. Efficiency of energy conversion during the day

In Figure 4 it can be seen that the efficiency of energy conversion under different conditions of solar radiation is higher for multicrystalline module. It is also be seen that efficiency is decreasing in contrast to increasing solar radiation. This situation can be caused by increase of module temperature [17]. The instantaneous decrease of efficiency observed in Figure 4 can be probably caused by shadows of people visiting the laboratory. Comparing the Figures 4, 3 and 2 can observe that in the first part of test together with efficiency decrease the temperature of modules is growing up from $39^{\circ} \mathrm{C}$ to even $51{ }^{\circ} \mathrm{C}$. 
In the last part of the test temperature of modules is decreasing and efficiency of modules increases in this moment.

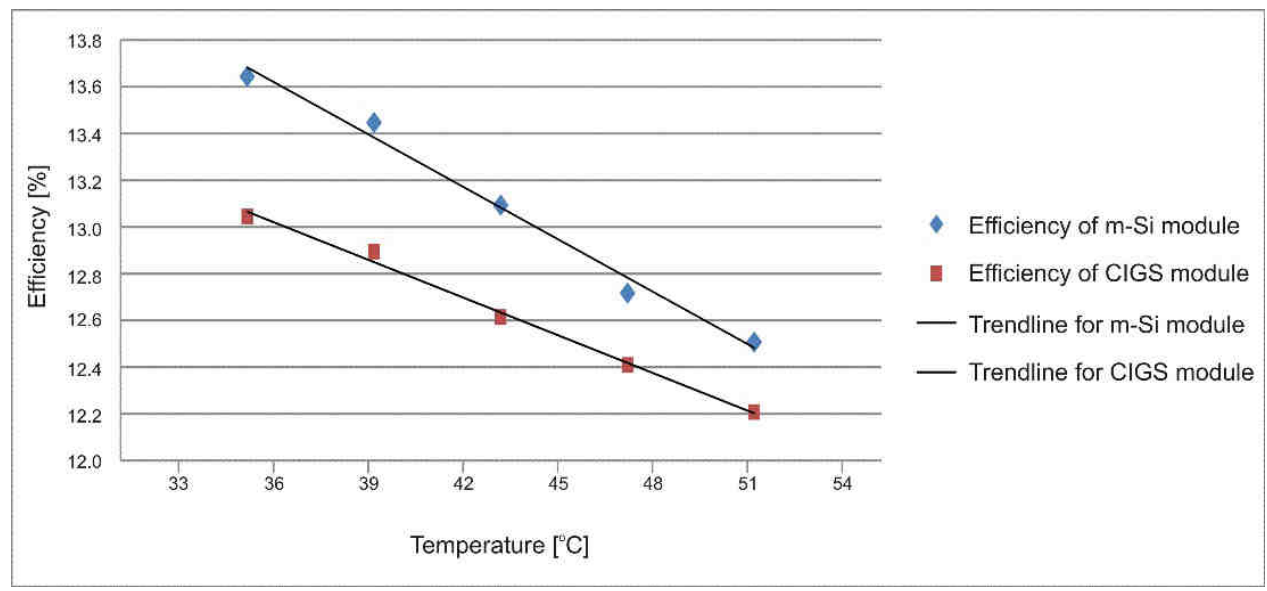

Fig. 5. The impact of temperature on the energy conversion efficiency

To show this phenomenon in more detail, curves in Figure 5 present how the efficiency of energy conversion for PV panels is changing for different temperatures and for constant solar radiation. The average temperature of modules was changing from 34.9 to $51.7^{\circ} \mathrm{C}$. The value of solar radiation was almost the same for each measurement and was about $691 \mathrm{~W} / \mathrm{m}^{2}$. In Figure 5 can be observed that the efficiency of energy conversion of each tested modules decrease with increasing temperature. The efficiency drop is more visible for $\mathrm{m}$-Si PV modules. This means that $\mathrm{m}$-Si module works worse with higher temperature and CIGS modules are more resistant to increase the temperatures modules.

Comparison of temperature power coefficients

\begin{tabular}{|c|c|c|c|c|c|}
\hline $\begin{array}{c}\text { Type of } \\
\text { module }\end{array}$ & $\begin{array}{c}\text { The lowest analysed } \\
\text { temperature of modules } \\
\text { with solar radiation } \\
\mathbf{6 9 1 . 4} \mathbf{~ W / \mathbf { m } ^ { 2 }} \\
{\left[{ }^{\circ} \mathbf{C}\right]}\end{array}$ & $\begin{array}{c}\text { The highest analysed } \\
\text { temperature of modules } \\
\text { with solar radiation } \\
\mathbf{6 9 1 . 1} \mathbf{~ W / \mathbf { m } ^ { 2 }}\left[{ }^{\circ} \mathbf{C}\right]\end{array}$ & $\begin{array}{c}\text { Real power } \\
\text { in low } \\
\text { temperature } \\
{[\mathbf{W}]}\end{array}$ & $\begin{array}{c}\text { Real power } \\
\text { in high } \\
\text { temperature } \\
{[\mathbf{W}]}\end{array}$ & $\begin{array}{c}\text { Temperature } \\
\text { power } \\
\text { coefficient } \\
{[\% / \mathbf{K}]}\end{array}$ \\
\hline $\mathrm{m}-\mathrm{Si}$ & 35.5 & 50.5 & 153.5 & 140.6 & 0.6 \\
\hline $\mathrm{CIGS}$ & 34.4 & 52.9 & 195.9 & 183.3 & 0.3 \\
\hline
\end{tabular}

Inverters used with PV modules are different what is related e.g. with maximum MPPT DC voltage of PV panels. During the sizing the PV system it is important to take into account temperature power coefficient [18] to ensure that the output voltage is not too high, which could damage the equipment. In the data sheet of PV modules the temperature power coefficient can be found. It is $0.31 \% / \mathrm{K}$ for CIGS module and $0.45 \% / \mathrm{K}$ for $\mathrm{m}-\mathrm{Si}$ module.

To determine the temperature power coefficient based on data collected to illustrate the impact of temperature on the efficiency of PV panels. Data presented in Table 3 correspond to the same solar radiation $691 \mathrm{~W} / \mathrm{m}^{2}$ in different time. Temperatures of modules were different during the measurements which made it possible to specify the temperature power 
coefficient. Due to test the CIGS modules are more resistant for temperatures changes than multicrystalline module. It may also be noted that the field test result coincides with data sheet in the case of CIGS module, however for $\mathrm{m}$-Si module experimental results and data given by producer are divergent.

Analysis of the energy produced by PV panels in specified time on the side of direct current and alternating current in the same moment allowed to define the efficiency of micro inverters. To studies three days with low, medium and high irradiation were selected. In order to avoid inhomogeneous shading effect, data from the range from 10 am to $15 \mathrm{pm}$ during the day were subjected to investigation. The average value of solar radiation was calculated based on the data registered every minute. Changes of solar radiation during the day are shown in Figure 6. The average values of solar radiation for which inverters efficiency was examined are $176.9,342.4$ and $692.8 \mathrm{~W} / \mathrm{m}^{2}$. Moreover values of insulation were calculated and shown in Table 4 . During the time of average solar radiations values were measured also the values of irradiance were calculated. Inverters efficiency was calculated using the formula:

$$
\eta_{\text {inverter }}=\frac{\text { Energy production in specified period on alternating current side } \mathrm{AC}[\mathrm{kWh}]}{\text { Energy production in specified period on direct current side } \mathrm{DC}[\mathrm{kWh}]}
$$

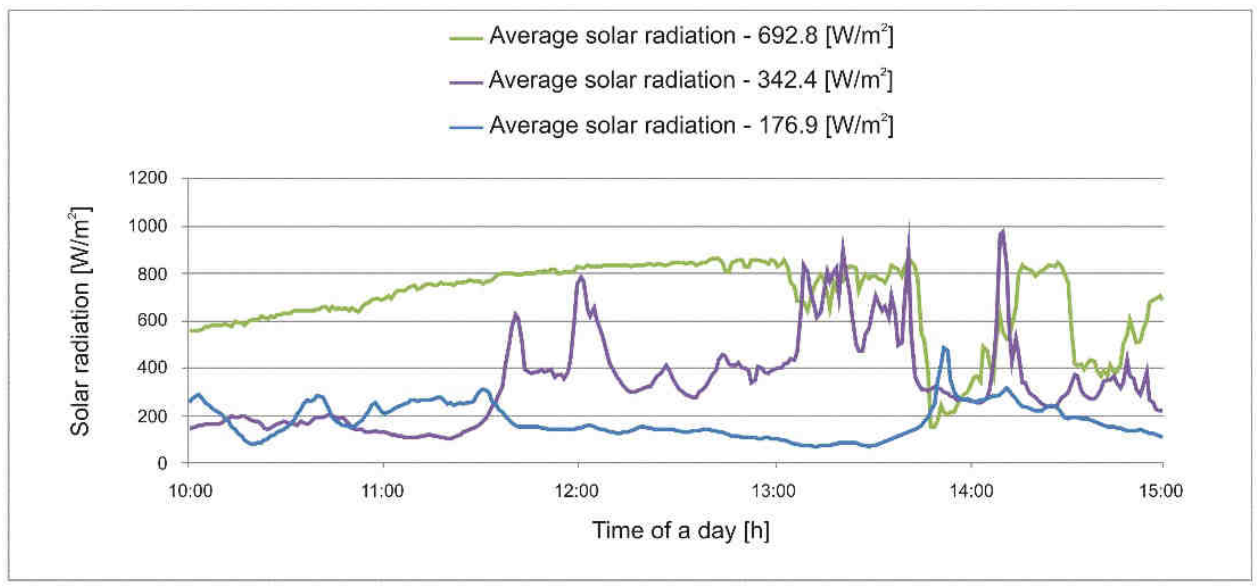

Fig. 6. Graph of low, medium and high solar radiation in the test of efficiency of inverters

All analysed data are given in Table 4 to specify efficiency of inverters. One can observed that with the increasing of solar radiation the efficiency of both inverters is growing up. Increase of the efficiency is similar for both devices, what is shown in the Figure 7. The reason for increasing the efficiency of the inverter with the increase of solar radiation is the higher inverter load. It is also very important that inverter working with $\mathrm{m}$-Si panel works better than inverter working with CIGS panel. It is noticeable for each test value of solar radiation. This may be due to the quality of the device. But also incomplete load of inverter may be the reason why the Stecagrid inverter works worse. Nominal power on the DC side of the Reneplus inverter is $250 \mathrm{~W}$ and works with PV panel, whose nominal power is $250 \mathrm{~W}$. Nominal power on the DC side of the Stecagrid inverter is $300 \mathrm{~W}$ and works with PV panel, whose nominal power is $280 \mathrm{~W}$. It is known, that 
inverters works with the highest efficiency, when are fully loaded. So the nominal power of PV panel should be equal to the nominal power of inverter or could be even bit higher [19].

Table 4

Energy production in different conditions of solar radiation

\begin{tabular}{|c|c|c|c|c|c|c|c|}
\hline \multicolumn{2}{|c|}{ Date } & \multicolumn{2}{|c|}{27.08 .2014} & \multicolumn{2}{|c|}{09.09 .2014} & \multicolumn{2}{|c|}{06.09 .2014} \\
\hline & Interval time & \multicolumn{2}{|c|}{$10.00-15.00$} & \multicolumn{2}{|c|}{$10.00-15.00$} & \multicolumn{2}{|c|}{$10.00-15.00$} \\
\hline \multicolumn{2}{|c|}{$\begin{array}{c}\text { The average solar radiation in specified } \\
\text { interval time }\left[\mathrm{W} / \mathrm{m}^{2}\right]\end{array}$} & \multicolumn{2}{|c|}{177} & \multicolumn{2}{|c|}{342} & \multicolumn{2}{|c|}{693} \\
\hline \multicolumn{2}{|c|}{$\begin{array}{c}\text { Insolation in specified interval time } \\
{\left[\mathrm{Wh} / \mathrm{m}^{2}\right]}\end{array}$} & \multicolumn{2}{|c|}{882} & \multicolumn{2}{|c|}{1706} & \multicolumn{2}{|c|}{3464} \\
\hline & Type of PV module & $\mathrm{m}-\mathrm{Si}$ & CIGS & $\mathrm{m}-\mathrm{Si}$ & CIGS & $\mathrm{m}-\mathrm{Si}$ & CIGS \\
\hline \multicolumn{2}{|c|}{ Nominal power of PV module [kW] } & 0.25 & 0.28 & 0.25 & 0.28 & 0.25 & 0.28 \\
\hline \multicolumn{2}{|c|}{ Area of PV module $\left[\mathrm{m}^{2}\right]$} & 1.63 & 2.17 & 1.63 & 2.17 & 1.63 & 2.17 \\
\hline \multirow{3}{*}{$\begin{array}{l}\mathrm{DC} \\
\text { side }\end{array}$} & $\begin{array}{l}\text { Energy produced within the } \\
\text { analysed time period }[\mathrm{kWh}]\end{array}$ & 0.25 & 0.28 & 0.42 & 0.5 & 0.75 & 0.97 \\
\hline & $\begin{array}{l}\text { Energy recalculated per } \mathrm{kWp} \text { on } \\
\text { the DC side }[\mathrm{kWh} / \mathrm{kWp}]\end{array}$ & 0.98 & 1.02 & 1.66 & 1.8 & 3.01 & 3.47 \\
\hline & $\begin{array}{l}\text { Energy recalculated per square } \\
\text { meter on the DC side }\left[\mathrm{kWh} / \mathrm{m}^{2}\right]\end{array}$ & 0.15 & 0.13 & 0.26 & 0.23 & 0.46 & 0.45 \\
\hline \multirow{3}{*}{$\begin{array}{l}\mathrm{AC} \\
\text { side }\end{array}$} & $\begin{array}{l}\text { Energy produced within the } \\
\text { analysed time period }[\mathrm{kWh}]\end{array}$ & 0.22 & 0.23 & 0.39 & 0.44 & 0.74 & 0.89 \\
\hline & $\begin{array}{c}\text { Energy recalculated per } \mathrm{kWp} \text { on } \\
\text { the } \mathrm{AC} \text { side }[\mathrm{kWh} / \mathrm{kWp}]\end{array}$ & 0.88 & 0.82 & 1.56 & 1.57 & 2.96 & 3.18 \\
\hline & $\begin{array}{l}\text { Energy recalculated per square } \\
\text { meter on the AC side }\left[\mathrm{kWh} / \mathrm{m}^{2}\right]\end{array}$ & 0.13 & 0.11 & 0.24 & 0.2 & 0.45 & 0.41 \\
\hline \multicolumn{2}{|r|}{ Efficiency of micro inverters $[-]$} & 0.89 & 0.81 & 0.94 & 0.87 & 0.98 & 0.91 \\
\hline
\end{tabular}

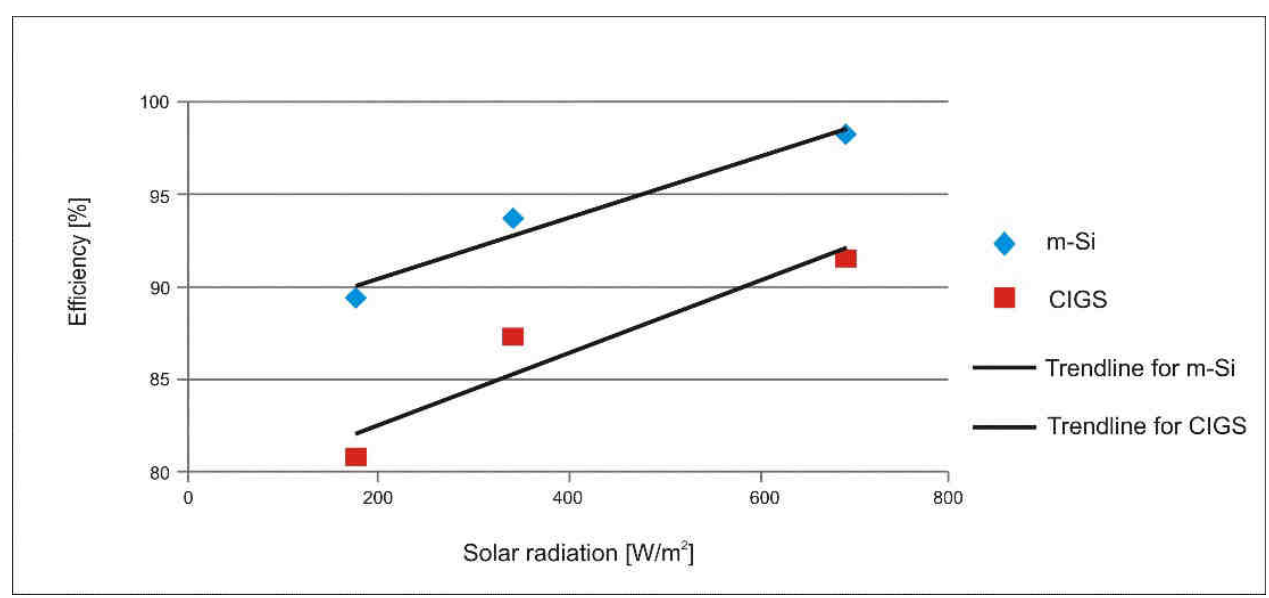

Fig. 7. Graph of inverters efficiency on solar radiation

To accurately determine the efficiency of inverters the measuring installation should be rebuilt and consist with two tested devices loaded by the same types of modules with similar nominal power. The problem is that sometimes it isn't possible to do. Designing photovoltaic installation should be remembered to choose inverter with parameters such as MPPT DC voltage range, maximum input short circuit current, maximum usable DC input 
power whose are in the good agreement with PV panel parameters. In this case thin film modules have high voltage range so they have to work with inverters with high DC voltage range. It is necessary to mention that the market does not offer too much choice of micro inverters with high DC voltage range. It is possible that inverter Stecagrid working with smaller Si - PV modules connected in series circuit will has a higher efficiency, what will be a part of future research.

\section{Summary and conclusion}

Research released in Laboratory of RES in Miekinia allows to compare different PV modules in long-term outdoor test. Performance of polycrystalline and CIGS modules was compared based on the results of outdoor measurements as well as based on the simulation carried out using PV SOL Expert 6.0 software. Energy yields recalculated per square meter and per $\mathrm{kWp}$ are similar for outdoor tests and performed simulations (Table 1). Energy production per $\mathrm{kWp}$ is higher for CIGS module than $\mathrm{m}-\mathrm{Si}$ module, while $\mathrm{m}$-Si module produces more energy from square meter what is connected with the efficiency of energy conversion. During a recent study comparing the multicrystalline module and thin-film CIGS module shows huge impact of module temperature on the efficiency of energy conversion. Thin film modules are more resistant to temperature effects and have less temperature power coefficient. As a result of tests it is presented the efficiency of inverters increase with the solar radiation. Moreover, Reneplus inverter, working with $\mathrm{m}$-Si module, revealed higher efficiency in measurement conditions.

In this moment other installation is built to research PV module with glass supported by antireflective layer used to improve the production of energy from the module [20, 21]. Moreover in the nearest future another position will be created to determine the impact of shading on individual technologies in photovoltaic modules and to study the influence of dust on the production of energy by the PV modules.

\section{Acknowledgements}

The paper prepared under AGH-UST statutory research grant No. 11.11.140.321 and was financially supported by the European Union from the Sources of the European Regional Development Fund for 2007-2013, the Innovative Economy Operational Program Priority Axis 1 - Research and Development of State-of-the-art Technologies POIG.01.03.01-30-056/12.

\section{References}

[1] Ginley DS, Cahen D. Fundamentals of Materials for Energy and Environmental Sustainability. Cambridge: Cambridge University Press; 2011.

[2] Peter LM. Philos Trans R Soc A. 2011;369:1840-1856. DOI: 10.1098/rsta.2010.0348.

[3] Jayarama Reddy P. Science and Technology of Photovoltaics, 2nd ed. BS Publications; 2010.

[4] Wenham SR, Green MA, Watt ME, Corkish R. Applied Photovoltaics. 2nd ed. London: Earthscan; 2007. DOI: $10.4324 / 9781849770491$.

[5] Hosenuzzamana M, Rahima NA, Selvaraja J, Maleka ABMA, Nahara A. Renew Sustain Energy Rev. 2015;41:284-297. DOI: 10.1016/j.rser.2014.08.046.

[6] Singh GK. Energy. 2013;53:1-13. DOI: 10.1016/j.energy.2013.02.057.

[7] Wenham SR, Green MA. Prog Photovoltaics. 1996;4:3-33. DOI: 10.1002/(SICI)1099-159X(199601/02) 4:1<3::AID-PIP117>3.0.CO;2-S.

[8] Orbey N, Norsworthy G, Birkmire RW, Russell TWF. Prog Photovoltaics. 1998;6:79-86. DOI: 10.1002/(SICI)1099-159X(199803/04)6:2<79::AID-PIP203>3.0.CO;2-N . 
[9] Krc J, Topic M. Optical Modeling and Simulation of Thin-Film Photovoltaic Devices. Boca Raton: CRC Press; 2016.

[10] Philipps S. Photovoltaics Report. Fraunhofer Institute for Solar Energy Systems, ISE; 2017. https://www.ise.fraunhofer.de/en/publications.

[11] Skoplaki E, Palyvos JA. Sol Energy. 2009;83(5):614-624. DOI:10.1016/j.solener.2008.10.008.

[12] Jain VK, Verma A. Environmental Science and Engineering. Physics of Seminonductor Devices. 2013:375-378. DOI: 10.1007/978-3-319-03002-9.

[13] Kurnik J, Jankovec M, Brecl K, Topic M. Sol Energy Mater Sol Cells. 2011;95:373-376. DOI: 10.1016/j.solmat.2010.04.022.

[14] Rodziewicz T, Teneta J, Zaremba A, Wacławek M. Ecol Chem Eng S. 2012;20(1):177-198. DOI: 10.2478/eces-2013-0014.

[15] Muñoz-García MA, Marin O, Alonso-García MC, Chenlo F. Sol Energy. 2012;86(12): 3049-3056. DOI: 10.1016/j.solener.2012.07.015.

[16] Sharma V, Kumar A, Sastry O, Chandel SS. Energy. 2013;58:511-518. DOI: 10.1016/j.energy.2013.05.068.

[17] Craciun D, Helmbrecht V, Tselepis S, Kyritsis A, Hatziargyriou N, Latoufis K, et al. Harmonised procedures on photovoltaic modules long-term energy yield measurements and performance evaluation under outdoor conditions. 27th Europ Photovolt Solar Energy Conf Exhibit. Frankfurt, Germany 24-28 September 2012. DOI: 10.4229/27thEUPVSEC2012-4CO.12.5.

[18] Ishii T, Otani K, Takashima T. Prog Photovoltaics. 2011;19(2):141-148. DOI: 10.1002/pip.995.

[19] Häberlin H, Photovoltaics System Design and Practice. Chichester: Wiley; 2012.

[20] Marszałek K, Winkowski P, Jaglarz J. Mater Sci-Pol. 2014;32(1):80-87. DOI: 10.2478/s13536-013-0156-y.

[21] Marszałek K, Jaglarz J, Sahraoui B. Opt Mater. 2015;39:1-7. DOI: 10.1016/j.optmat.2014.09.041. 